\title{
¿Crece la conflictividad escolar? Percepciones de estudiantes y profesorado de Secundaria
}

Is school climate improving? Secondary students and teachers' perceptions of conflictivity

\author{
InMaculada Hernando Mora*1 \\ mi.hernando@ucv.es \\ Roberto Sanz Ponce* \\ roberto.sanz@ucv.es \\ * Universidad Católica de Valencia, España \\ * Instituto Universitario de Teoría de la Educación, España
}

\begin{abstract}
Resumen:
La conflictividad escolar, un tema que ha sido estudiado en profundidad en los últimos años, preocupa a gran parte de la sociedad. Durante cierto tiempo, el acoso escolar ha seguido una trayectoria ascendente, sin embargo, han comenzado a aparecer nuevos estudios que demuestran que el clima escolar está mejorando.

El objetivo de este artículo es comprobar si realmente el clima escolar está mejorando, mediante dos encuestas basadas en las percepciones de los profesores y de los alumnos, que fueron realizadas durante los cursos 1998/1999 y 2011/2012 por diferentes investigadores. La muestra total incluía a más de 4.000 profesores y estudiantes de tercer curso de Educación Secundaria.

Los resultados muestran que, según los participantes, los estudiantes no presentan comportamientos especialmente problemáticos y que el clima escolar es positivo. La mayoría de las agresiones son verbales y los estudiantes problemáticos se limitan a entorpecer el curso de las clases. A pesar
\end{abstract}

\begin{abstract}
:
A large part of society is concerned about school conflict, a subject that has been studied in depth over the last few years. Over a period of time bullying was on the rise. However, new studies that show that school climate is improving have started to appear.

The aim of this paper is to verify if really school climate is improving by means of two surveys based on pupils and teachers' perceptions of school conflict, conducted in 1998/1999 and 2011/2012 by different researchers. The total sample consisted of over 4,000 secondary teachers and students in their third year of secondary school.

Results show that, in the participants' opinion, students are not especially troubled and school climate is positive. The most frequent aggressions are of a verbal nature and troubled students just disrupt the course of the classes. In spite of this, there are $15 \%$ of unmotivated teachers because of school conflict. It was also noticed that family situations affect student achie-
\end{abstract}

1 Dirección para correspondencia (correspondence address):

Inmaculada Hernando Mora. Facultad de Magisterio y Ciencias de la Educación. Universidad Católica de Valencia. C/ Sagrado Corazón, 5. 46110 Godella (España). 
¿Crece la conflictividad escolar? Percepciones de estudiantes y profesorado de Secundaria

inmaculada Hernando Mora y Roberto Sanz Ponce

de ello, un $15 \%$ de los profesores se sienten desmotivados debido a la conflictividad escolar. También se ha comprobado que la situación familiar afecta a los resultados escolares. El porcentaje de estudiantes que repiten curso es mayor en aquellos hogares desestructurados y en aquellos en los que las madres se ausenta por motivos laborales.

Se ha comprobado que la conflictividad ha disminuido en comparación con el primer estudio (García y Martínez, 2001).

\section{Palabras clave:}

Conflictividad escolar; clima escolar; acoso; violencia verbal; profesores desmotivados; educación secundaria. vement. The percentage of students who had retaken a year was higher in broken homes and when mothers worked outside home.

The results show that conflict has decreased compared to the first study (García \& Martínez, 2001).

\section{Keywords:}

School conflict; climate school; bullying; verbal violence; unmotivated teachers; secondary education.

\section{Résumé:}

Le conflit scolaire, un sujet qui a été étudié en profondeur ces dernières années, inquiète une grande partie de la société. Durant un certain temps, le harcèlement scolaire a suivi une trajectoire croissante. Cependant, de nouvelles études démontrent que le climat scolaire s'améliore.

L'objectif de cet article sera de savoir si le climat scolaire s'améliore réellement. Et ce, grâce à deux enquêtes basées sur les perceptions de professeurs et d'élèves, datant des années académiques 1998/1999 et 2011/2012. L'échantillon total englobait plus de 4 000 professeurs et élèves de la $3^{\text {ème }}$ année de l'Education Secondaire.

Les résultats montrent que, selon les participants, les élèves ne présentent aucun comportement particulièrement problématique et que le climat scolaire est positif. La majorité des agressions son verbales et les étudiants problématiques se limitent à déranger les cours. Malgré cela, les professeurs sont 15\% à se sentir démotivés à cause du conflit scolaire. Nous avons aussi voulu rendre compte de la situation familiale et son attachement aux résultats scolaires. Le pourcentage d'élèves redoublants est plus élevé s'ils vivent dans un foyer déstructuré ou dans lesquels les parents sont absents, pour des raisons professionnelles ou autres.

Nous avons également remarqué que les problèmes de conflit sont en baisse, si nous les comparons à la première étude (García et Martínez, 2001).

\section{Mots clés :}

Conflit scolaire; climat scolaire; harcèlement; violence verbale; professeurs démotivés; éducation secondaire.

\section{Fecha de recepción: 18-5-2017}

Fecha de aceptación: 21-9-2017 


\section{Introduction}

Large part of society is concerned about school conflictivity, a subject that has been studied in depth over the last few years. Since the research on bullying of Dan Olweus in the 1980s (Olweus, 1993), there have been a lot of studies about conflicts. In relation to kinds of conflicts, authors like Bjorkvist, Lagerspetz \& Kaukiainen (1992), Atkins, Stoff, Osborne \& Browne (1993), Crick \& Grotpeter (1995) Archer \& Coyne (2005) and Zimmer-Gemback, Geiger \& Crick (2005), describe different classifications that join three great groups of conflicts (physical, psychological and verbal violence). Some authors (Slee \& Rigby, 1993; Baldry \& Farrington, 1998; Anderson et al. 2003; Berguno, Leroux, McAinsh \& Shaikh, 2004; Andreou, 2000, 2001, 2004 and 2006; Cava, Musitu \& Murgui, 2007; Pelegrín \& Garcés de los Fayos, 2008; De Bruyn, Cillessen \& Wissink, 2010), differ four principal causes of conflicts: familiar, social, personal and scholar causes. Other studies (Baldry \& Farrington, 2005; Gentile et al, 2009; Greitemeyer \& Osswald, 2009;) affirm that the lack of protective factors among young people, joined to risk factors increases noticeably the likelihood of violent situations in school. The lack of role models and models of behaviour becomes in a fundamental cause of school violence. On the other hand, consequences of school conflicts (Rigby, 2000; Bauman, Toomey \& Walker, 2013; McCabe, Miller, Laugesen, Antony \& Young, 2010), affect not only the scholar context but also the personal and social ones. In the personal area, conflicts affect in different ways as much in case of the victims as in that of the harassing ones. In both cases, these are young people in the process of formation. The social consequences affect the view of school and teacher and their social status. The social alarm caused by conflicts and raised by media leads to a negative view of role of school and teacher. Eventually, on the scholar scale conflicts affect the classroom climate. There are as well a lot of studies about prevalence rates (Boulton \& Smith, 1994; Baldry \& Farrington, 1998; Borg, 1999; Berthold \& Hoover, 2000; Defensor del Pueblo-UNICEF, 2000 and 2007; García \& Martínez, 2001; Ramos, 2008).

All these studies have provided a larger knowledge about school conflictivity and interest in this phenomenon has grown (Andreou, 2015). People are more sensitive to it now and feel alarm about it. For several years there has been a public awareness of an increasing bullying trajectory. However new studies that show that school climate is improving have 
¿Crece la conflictividad escolar? Percepciones de estudiantes y profesorado de Secundaria

Inmaculada Hernando Mora y Roberto Sanz Ponce

started to appear: Rigby \& Smith (2011) found significant decreases in buIlying in many countries; Schneider, O`Donnel and Smith (2015) found as well a decrease in bullying among boys from 2006 to 2012 (25\% to 18\%); in a longitudinal study made in Spain at a national-scale, the incidence of several forms of bullying in secondary schools between 1999 and 2006 was shown (Defensor del Pueblo-UNICEF, 2007); Perlus, Brooks-Russell, Wang and lannotti (2017) studied trends in bullying victimization in Scottish adolescents between 1994-2014, finding as well that the prevalence of bullying perpetration, bullying victimization, and physical fighting have decreased; and the same was found by Vieno, Lenzi, Gini, Pozzoli, CavaIlo and Santinello among Italian middle and secondary school students, between 2002 and 2010. In addition, from what Chester, Callaghan, Cosma, Donelly, Craig, Walsh \& Molcho say, trends in bullying victimization among adolescent students have decreased in a third of the 33 European countries that participated in a study from 2002 to 2010.

The aim of this paper is to present the results of two surveys based on pupils and teachers' perceptions of school conflictivity, conducted in 1998/1999 and 2011/2012 by different researchers in Valencia (Spain). In either case the surveys used were the statistically validated Questionnaires about Conflicts in Secondary Schools, developed by the professor Juan Escámez et al. (García \& Martínez, 2001). In 1999 these surveys were completed by a sample of 447 in-service secondary teachers and 3,328 pupils in Grade 3 from 36 secondary schools of the Valencian Community (Spain). The same study was done again in order to analyze the conflictivity during the school year 2011/2012 and compared it to the mencioned study. The surveys were completed by a sample of 271 inservice secondary teachers and 709 pupils in Grade 3 from 25 secondary schools of Valencia city. In spite of the fact that the results of both studies were similar, evidences that school climate had improved were found.

\section{First report on school conflicts in Valencian Community (García \& Martínez, 2001)}

Results show that, in the participants' opinion, students were not often troubled and school climate was positive. The most frequent aggressions were the verbal ones and troubled students just hampered the course of the classes. Despite this, there was forty per cent of unmotivated teachers 
and seven per cent of teachers wished to find another way to make a living because of school conflictivity. Furthermore, more than half of the teachers have not felt ready to face the issue.

As for the students, fifty per cent said that climate was nice whereas sixty-two per cent reported a negative view of teachers and ninety-seven per cent had a negative view of classmates' behavior.

In the results and discussion sections further details are presented.

\section{Method}

The Questionnaires about Conflicts in Secondary Schools (García \& Martínez, 2001) consisted of 5 surveys for secondary teachers, pupils, head teachers, counselors and troubled students' tutors. This study is just going to be based on the results of teachers and pupils surveys. Every survey consisted of two sections. Although surveys were anonymous, in the first section respondents gave some personal details as age or gender. In the second section they reported their opinion about school conflictivity.

The pupils' surveys were designed to assess their instrumental and ethical-civic competences and their opinion in relation to conflicts. The section about instrumental competences was a six-item questionnaire consisting of 3-point Likert scale (range from "always" through to "hardly ever"). The section about ethical-civic competences was an 11-item questionnaire consisting of 3-point format (range from "much" through to "nothing"). The section about pupils' opinion in relation to conflicts was a 17-item questionnaire consisting of 3-point format ("yes", "no", and "I don't know").

In teachers' surveys, the respondents should reflect about conflictivity in their school (the most frequent conflict type or place, people involved, causes, consequences, intervention). The teachers should select from three $\mathrm{o}$ more answers. Two items consisted of 3-point Likert scale and 9 items consisted of multiple choice answers. These last ones were subsequently converted to dummy variables because of teachers have chosen more than one answer.

Schools were selected by a stratified cluster sampling method based on ownership and location of schools. A total of 59 secondary schools (16 of whom were public schools) were invited to participate in the investigation. Twenty-five schools were only get involved, 3 of whom public schools. Even so almost all the postal districts of Valencia city were included. Statistical accuracy of surveys calculated by population pro- 
¿Crece la conflictividad escolar? Percepciones de estudiantes y profesorado de Secundaria

Inmaculada Hernando Mora y Roberto Sanz Ponce

portion according to Prieto \& Herranz (2005), with a confidence level of $95 \%$ and a $z$ value of 1.96 was $3.68 \%$ in the case of students' survey and $5.95 \%$ in the case teachers' survey.

Frequency analyses, $\mathrm{Chi}^{2}$ tests, non-parametric tests and logistic regression were calculated with SPSS/PC.

\section{Results}

\section{Teachers' perceptions in relation to conflicts}

A total of 271 secondary teachers (62 per cent women and 38 per cent men) completed questionnaires appropriately. In relation to conflicts, $82.7 \%$ of the teachers reported that the most frequent one was verbal violence; $38,8 \%$ said that conflicts happened mainly in the playground; $56.8 \%$ said that the most frequent cause was values crisis, followed by family situation (48.7\%) and lack of student motivation (40.6\%); and $43.5 \%$ of the teachers reported that the most important consequence was that it prevented students from learning.

Table 1 shows first causes of conflicts according to teachers. Between 1999 and 2012, a significant increase in the percentage of teachers who reported that conflicts are due to especially, the family situation has been found, both in private $(44.5 \%)$ and public schools $(66.7 \%)$. The same went with the variable "values crisis" $(58.2 \%$ and $41.0 \%$ in private and public school, respectively, compared to $23.6 \%$ in 1999). The lack of student motivation (the most important cause in 1999) would continue being an important cause for teachers of public schools (62.7\%) although it would be less important for teachers of private schools (35.5\%).

Table 1. Probability of the most important dummy variables about causes of conflicts.

\begin{tabular}{lccc}
\hline Dummy variables & 1999 & 2012 & $\mathrm{p}$ \\
\hline Family situation & 0.190 & 0.487 & $<0.0001^{*}$ \\
Lack of student motivation & 0.520 & 0.406 & $0.0022^{*}$ \\
Values crisis & 0.286 & 0.568 & $<0.0001^{*}$ \\
Poor schooling & 0.213 & 0.151 & $0.0421^{*}$ \\
Lack of teachers' training & 0.034 & 0.018 & 0.2310 \\
Misapplication of education law & 0.132 & 0.029 & $<0.0001^{*}$ \\
\hline
\end{tabular}

* Significant statistically differences in Chi2 test. 
It should be highlighted the low percentage of teachers who linked the school background with the causes of conflicts (poor schooling, lack of teachers' training or a misapplication of education law). More than $80 \%$ of the teachers linked these causes with the social or family background or with the same student.

Regardless age, gender or teaching experience, teachers reported that violence mainly prevented students from learning and $31 \%$ of the respondents admitted to devote class time to get his students' attention. On the other hand, in spite of $82 \%$ of the teachers tried violence do not affect his teaching quality, there are $15 \%$ (25\% in public schools) of unmotivated teachers because of school conflictivity. Fortunately, this percentage is much lower than the result got in 1999 (40\%).

Moreover, $19 \%$ of the teachers admitted do not feel ready to face the conflicts, regardless age, training or teaching experience, but it has been found a significant difference of gender in that men would feel more ready than women to face them $(89 \%$ of men and $74.7 \%$ of women felt to be ready, $p=0.0010)$. The same went in relation to type of school: teachers of private schools would feel more ready than teachers of public schools to face the conflicts $(83.1 \%$ and $67.3 \%$ respectively, $\mathrm{p}=0.0368)$.

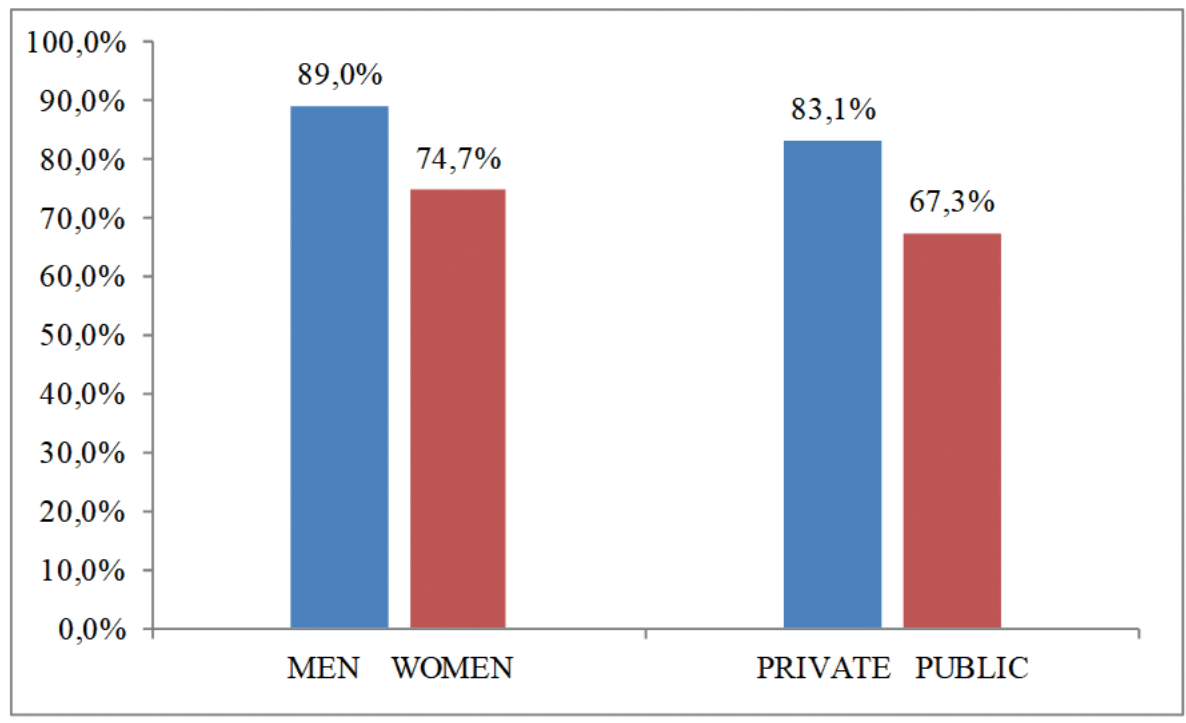

Figure 1. Teachers' perceptions in relation their training to face the conflicts. 
¿Crece la conflictividad escolar? Percepciones de estudiantes y profesorado de Secundaria

inmaculada Hernando Mora y Roberto Sanz Ponce

Students' perceptions in relation to their competences and school conflicts

A total of 709 students in their third year of secondary school (57 per cent women and 43 per cent men) completed questionnaires appropriately. Respondents' profile was a Spanish boy/girl, 14 or 15 years old, who has no repeated any year, and who lived with the two parents. Both parents were in work and students wanted to continue studying after completing secondary school. But there is also certain variability among students. There was $18 \%$ of immigrants (American, European or Asian students), 25\% of the respondents admitted having repeated some year, $17 \%$ did not want to continue studying, and $20 \%$ did not live with the two parents.

\section{Crosstabs analyses of students data}

Results indicated some statistically significant differences among students. For instance, boys were more likely to repeat some year than girls ( $29.7 \%$ of boys compared to $21.8 \%$ of girls, $p=0.00178)$, and students who lived with the two parents were less likely to repeat some year than students who did not live with them both $(22.7 \%$ of students who lived with the two parents compared to $37 \%$ of students who did not, $p=$ 0.0004). Furthermore, when only the father worked, students were less likely to repeat some year $(18.7 \%)$ than when both parents $(23.2 \%)$, and only the mother $(44.2 \%)$, worked.

\section{Instrumental competences}

As can be seen in Table 3, in general terms, students understood teachers' explanations (96.4\% of the respondents) and they reported a good mathematics learning $(82.7 \%)$, but only $43.4 \%$ of students surveyed reported a good reading comprehension. Furthermore, students who worked in class were more likely to understand any reading (55\%) than students who did not work in class $(42 \%)(p<0.001)$. As for homework, $45 \%$ of the respondents admitted not to do it. 
Table 3. Some students' perceptions in relation to their instrumental competences.

\begin{tabular}{lccc}
\hline & $\begin{array}{c}\text { ALWAYS } \\
(\%)\end{array}$ & $\begin{array}{c}\text { SOMETIMES } \\
(\%)\end{array}$ & $\begin{array}{c}\text { HARDLY EVER } \\
(\%)\end{array}$ \\
\hline I do not understand teachers' explanations & 3.5 & 54.2 & 42.2 \\
I do my homework & 55.3 & 39.8 & 4.8 \\
I work in class & 67.9 & 29.4 & 2.7 \\
I have a good reading comprehension & 57.6 & 39.5 & 2.9 \\
I have not a good mathematics learning & 17.3 & 50.2 & 32.5 \\
\hline
\end{tabular}

\section{Ethical-civic competences}

Table 4 shows some students' perceptions in relation to their ethical-civic competences. In general terms, students did not row with their classmates and they obeyed to the teacher. They looked after school equipment and textbooks and they did not get annoyed when people did not do whatever they wanted or when they could not impose their way of thinking. But it is important to point out the high percentage of students who recognized that they did not like teamwork $(32.2 \%)$, or did not reconcile differences with classmates by dialogue $(28.3 \%)$, or did not think about whether they can hurt somebody or not before they do something $(46.4 \%)$, or did not admit their mistakes $(72.2 \%)$.

Table 4. Some students' perceptions in relation to their ethical-civic competences.

\begin{tabular}{lccc}
\hline & $\begin{array}{c}\text { VERY MUCH } \\
(\%)\end{array}$ & $\begin{array}{c}\text { NOT MUCH } \\
(\%)\end{array}$ & $\begin{array}{c}\text { NOT AT ALL } \\
(\%)\end{array}$ \\
\hline $\begin{array}{l}\text { I annoy when my classmates do not do } \\
\text { whatever I want }\end{array}$ & 3.8 & 39.5 & 56.7 \\
I like teamwork & 67.9 & 26.5 & 5.7 \\
I usually reconcile differences with & 71.1 & 24.0 & 4.3 \\
classmates by dialogue & 4.1 & 31.9 & 64.0 \\
I do not obey the teacher & 5.1 & 36.9 & 58.0 \\
I annoy when I cannot impose my way of & & & \\
thinking & 53.6 & 38.6 & 7.8 \\
$\begin{array}{l}\text { Before I do something I usually think } \\
\text { about whether I can hurt somebody or not }\end{array}$ & 3.3 & 30.8 & 66.0 \\
I row with my classmates & 57.8 & 38.9 & 33.3 \\
I recognize my mistakes & 65.3 & 29.6 & 5.1 \\
\hline I look after school equipment and textbooks & & & \\
\hline
\end{tabular}


¿Crece la conflictividad escolar? Percepciones de estudiantes y profesorado de Secundaria

inmaculada Hernando Mora y Roberto Sanz Ponce

Some significant differences emerged with crosstabs analysis. Boys were less likely to reconcile differences by dialogue than girls $(64.4 \%$ of boys compared to $77.8 \%$ of girls, $p=0.001)$, to obey the teacher $(59.0 \%$ of boys compared to 68.2 of girls, $p=0.041$ ) or to look after school equipment and textbooks ( $57.0 \%$ of boys compared to $71.8 \%$ of girl, $\mathrm{p}<0.001$ ).

Furthermore, behavior of students who wanted to continue studying after completing secondary school is better than the rest of students (Figure 2).

\section{Figure 2. Students behavior according to their mind to continue studying after completing secondary school.}

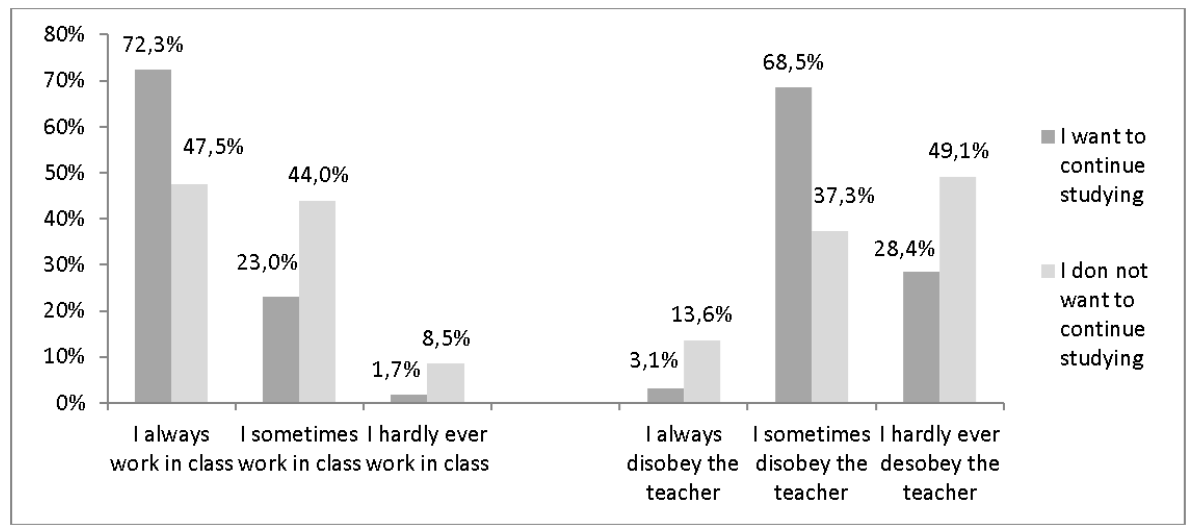

$P<0.001$, in both cases.

\section{School conflicts}

An increase in the percentage of students who reported that class climate was nice (from not much more than $50 \%$ in 1999 to $62 \%$ in 2012) has been found. Furthermore, the percentage of students who reported that class climate was not nice has decreased from $25 \%$ in 1999 to $16 \%$ in 2012. But it is important to point out some results presented on Table 5. On the one hand, students have not a really good image of teachers: about $20 \%$ of respondents claimed that teachers punish wrongly or that they do not know how to treat them, and $45.2 \%$ of the students reported that some teachers are too tough. On the other hand, classmates had not a really good image either. About $20 \%$ of the students claimed that some classmates force another ones to do something that they do not want to do or that some classmates swear at teachers, and $15.9 \%$ reported that some classmates mocked them in class. 
Table 5. Some students' perceptions in relation to school conflicts.

\begin{tabular}{lccc}
\hline & $\begin{array}{r}\text { YES } \\
(\%)\end{array}$ & $\begin{array}{c}\text { NO } \\
(\%)\end{array}$ & $\begin{array}{c}\text { DON'T }^{\prime} \text { KNOW (\%) } \\
\text { KN }\end{array}$ \\
\hline I go to high school because my parents force me to go 11,6 & 77,7 & 10,6 \\
I would like to move school & 13,9 & 68,4 & 17,7 \\
Going to school is a waste of time & 2,3 & 89,5 & 7,5 \\
The class climate is nice & 62,4 & 16,1 & 21,5 \\
Some students do not let teachers teaching & 70,3 & 13,9 & 15,8 \\
Some students swear at teacher & 19,1 & 61,6 & 19,3 \\
Somebody mocked me in class & 15,9 & 68,6 & 15,5 \\
Teachers punish wrongly & 20,4 & 52,8 & 26,8 \\
Some students force another ones to do something & 20,4 & 56,3 & 23,3 \\
that they do not want to do & 21,3 & 52,2 & 26,5 \\
Teachers do not know how to treat us & 5,7 & 90,6 & 3,7 \\
I am afraid of some classmates & 12,8 & 72,9 & 14,3 \\
There are a lot of violent guys in my class & 45,2 & 40,5 & 14,2 \\
Some teachers are too tough & 15,5 & 80,4 & 4,1 \\
\hline I have had some cyber conflict & &
\end{tabular}

All these factors affect the attachment of students to school in such a way that $16.1 \%$ of the respondents said that class climate was not nice, $13.9 \%$ of them would like to move school and $11.6 \%$ of the students admitted were forced to go to school. In fact, students who had a bad image of classmates or teachers were more likely to think that class climate is not nice, or to be forced to go to school or would like to move school (Figure 3). 
¿Crece la conflictividad escolar? Percepciones de estudiantes y profesorado de Secundaria

Inmaculada Hernando Mora y Roberto Sanz Ponce

Figure 3. Answers of students according to three variables: "I go to school because my parents force me to go", "I would like to move school" and "The class climate is nice".

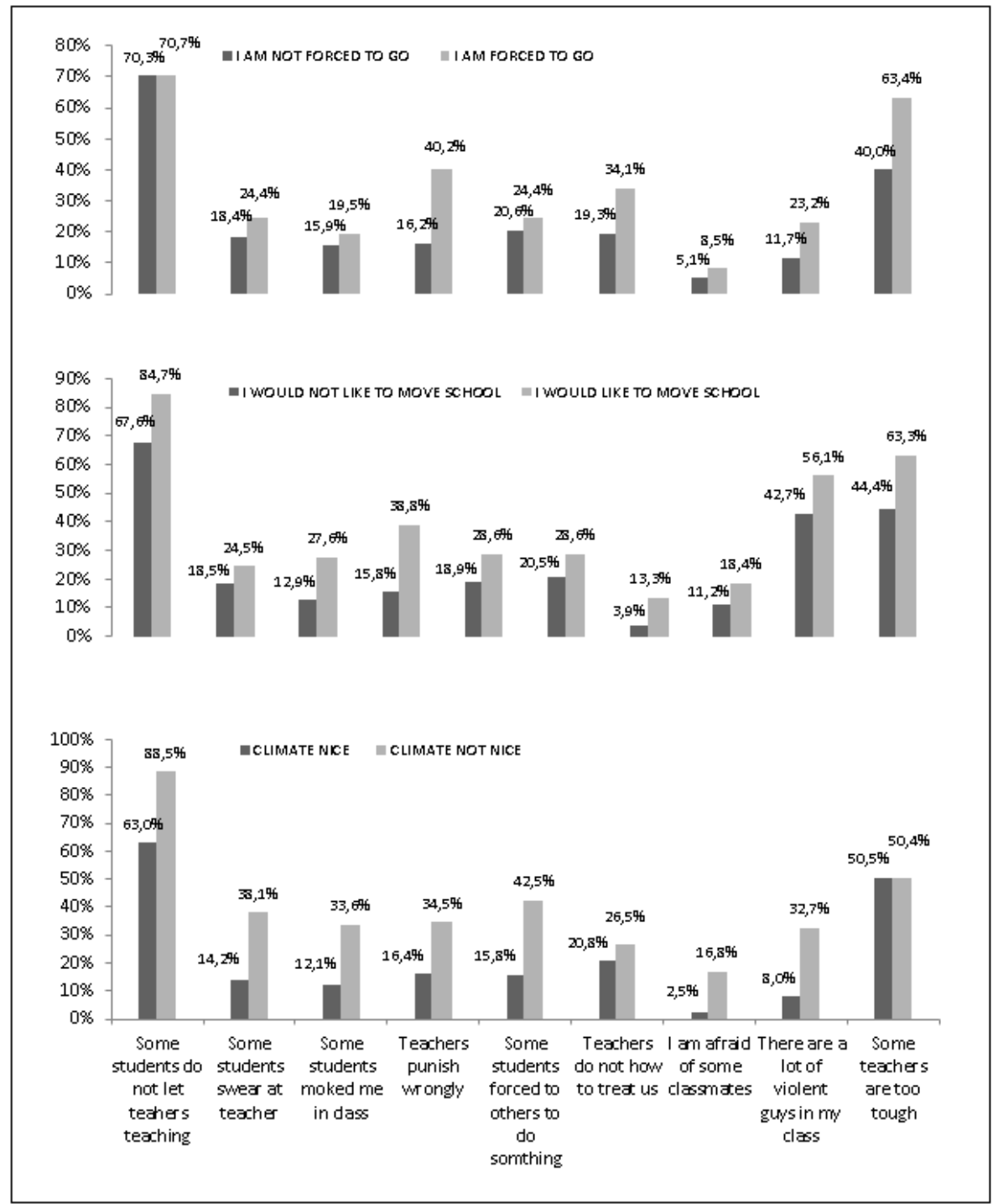

\section{Twostep cluster analyses}

In order to verify the results, a Twostep cluster analyses was made. This procedure has shown two clusters (Table 6), and differences between 
both clusters in relation to climate perception, being forced to go to school, and wishing to move have been found.

Table 6. Cluster distribution.

\begin{tabular}{llcc}
\hline \multirow{3}{*}{ Cluster } & & $\mathrm{N}$ & $\%$ Total \\
\cline { 3 - 3 } & 1 & 288 & $40.6 \%$ \\
& 2 & 384 & $54.2 \%$ \\
& Combined & 672 & $94.8 \%$ \\
& Excluded cases & 37 & $5.2 \%$ \\
& Total & 709 & $100.0 \%$ \\
\hline
\end{tabular}

As can be seen in Table 7, cluster 1 students are more positive than cluster 2 students. The percentage of students that to be forced to go to school, to wish to move or to think that climate is not positive is lower. These students included in cluster 1 have a better image of classmates or teachers and a lower likelihood of someone mock them in class or to repeat any year.

Table 7. Students' perceptions in relation to school conflicts. Frequency of students that said yes in each cluster.

\begin{tabular}{lcc}
\hline & $\begin{array}{c}\text { CLUSTER 1 } \\
\text { FREQUENCY } \\
(\%)\end{array}$ & $\begin{array}{c}\text { CLUSTER 2 } \\
\text { FREENCY } \\
(\%)\end{array}$ \\
\hline I go to high school because my parents force me to & 5.2 & 15.4 \\
go & 4.5 & 20.6 \\
I would like to move school & 0.7 & 3.9 \\
Going to school is a waste of time & 82.6 & 46.1 \\
The class climate is nice & 52.8 & 83.6 \\
Some students do not let teachers teach & 6.6 & 28.9 \\
Some students swear at teacher & 4.9 & 23.7 \\
Somebody mocked me in class & 3.5 & 32.3 \\
Teachers punish wrongly & 3.1 & 33.9 \\
Some students force another ones to do something & 0.0 & 9.4 \\
that they do not want to do & 0.3 & 21.9 \\
I am afraid of some classmates & 25.3 & 60.7 \\
There are a lot of violent guys in my class & 5.6 & 22.9 \\
\hline Some teachers are too tough &
\end{tabular}

$P \leq 0.001$ in all of the variables. 
¿Crece la conflictividad escolar? Percepciones de estudiantes y profesorado de Secundaria

inmaculada Hernando Mora y Roberto Sanz Ponce

\section{Friedman and Cochran analysis}

In view of categorical variables, Friedman and Cochran analysis for $\mathrm{k}$ related variables has been done. The results of the two studies much up with the frequency analysis: the general perception of school climate is positive, the most important conflict was that some students do not let teachers teach, and the second most important trouble was that some teachers are too tough.

Table 8. Friedman and Cochran tests.

\begin{tabular}{lccc}
\hline & $\begin{array}{c}\text { RANGES } \\
\text { (Friedman }\end{array}$ & \multicolumn{2}{c}{ FREQ } \\
\cline { 3 - 5 } (Cochran Test)
\end{tabular}

\section{Discussion}

In both Valencian studies, the results concerning kind of conflicts are consistent with the study about American adolescents described by 
Wang, lannoti and Nansel (2009), who found that the prevalence of involvement in bullying others, being bullied, or both of verbal violence was higher than the prevalence of another forms of violence as physical or electronic ones. This view is also supported by Oñederra (2004), Síndic de Greuges (2007) and Gobierno Vasco (1994), who referred that teachers, students and parents asserted that the most important conflict was verbal violence.

Other researchers found that the prevalence of physical conflicts was higher than the prevalence of verbal conflicts. The number of incidents included in the online Central Registry of the Valencian Board of Education between September 2007 and September 2008 shown that physical conflicts were more likely than verbal conflicts (Félix, Soriano and Godoy, 2009). Results of Iborra, Rodríguez, Serrano and Martínez (2010) were similar. These differences could be caused by the teachers mindset, who could consider verbal violence less serious than physical violence. Glover, Gough, Johnson and Cartwright (2000) found that teachers are less likely to intervene in resolving verbal bullying than physical bullying.

From what teachers said, incidence of psychological and physical violence was similar in both Valencian studies, verbal violence is higher in 2012 than in 1999, but vandalism has clearly decreased. Whereas, from what students said, psychological, physical and verbal violence have also decreased (Figure 4).

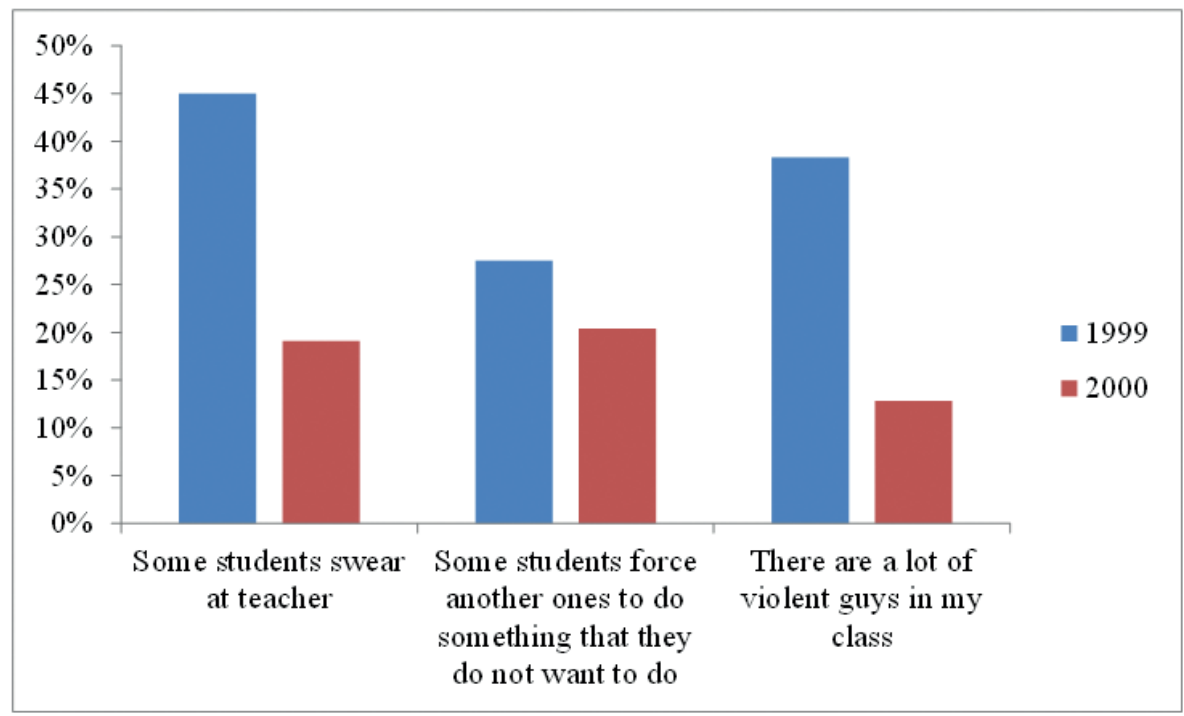

Figura 4. Students opinion about classmates' behavior. 
¿Crece la conflictividad escolar? Percepciones de estudiantes y profesorado de Secundaria

inmaculada Hernando Mora y Roberto Sanz Ponce

Avilés and Monjas (2005) found that in $85.5 \%$ of school conflicts there were no present teachers. Bradshaw, Sawyer and O'Brennan (2007) affirmed that teachers underestimated number of students involved in bullying. In addition, as Olweus (2006) pointed out, number of aggressions decrease as more teachers are watching over break security. All this could be the reason why results of students have not been according to results of teachers (percentage of students who were of the opinion that school conflicts took place outside of school was $54 \%$ against $20 \%$ of teachers).

On the other hand, teachers didn't link the school background with the causes of conflicts but with the social or family background or with the student. Their opinion agrees with the teacher's opinion in the study of Defensor del Pueblo (2007).

Results show that there are $15 \%$ of unmotivated teachers because of school conflictivity, but this percentage is much lower than 1999 results $(40 \%)$. The same were with percentage of teachers admitted do not feel ready to face the conflicts (12.6\% in 2012 against $56.9 \%$ in 1999). But students' opinion did not agree with those results. Although percentage of students who reported that class climate was not nice has decreased, there is $16 \%$ of students that believe it. Twenty percent of students claimed that teachers punish wrongly and $45.2 \%$ that teachers are tough. So, students who had a bad image of teachers or classmates were more likely to think that class climate is not nice. As for these results the Programme Pisa in Focus (OCDE, 2011 \& 2013) say that there is a close relation between positive attitude students towards their learning and positive attitude teachers in the classroom: when teachers respond to the students and listen and pay attention to them, they create a better climate and students enhance their achievement. In contrast to this report, the Valencian teachers linked the causes of conflicts with students or their social or family background ( $80 \%)$. They affirmed that there is a lack of motivation and an important crisis of values among young people. This supposed lack of motivation did not agree with students perception as only $14 \%$ of them wanted to move school and only $12 \%$ affirmed going to school because their parents force them to go. However, what teachers said about the crisis of values is consistent with the results, because these show that $32 \%$ of the students did not like teamwork, $28 \%$ did not reconcile differences with classmates by dialogue, $46 \%$ did not think about consequences of their acts and $72 \%$ did not admit their mistakes. 
As can be seen in Figure 1, there are important differences between what teachers needed in 1999 and they needed in 2012. Nowadays there is a greater social conscience about the need of pedagogical training. It is so important that in 2009 the short course CAP (Certificado de Aptitud Pedagógica) that lasted 3 months and every graduated needed to take for becoming secondary teacher was replaced by a new Master that lasts one year. Furthermore, a political debate about the possibility of this master could last two years was open.

This situation could be the cause why percentage of teachers who admitted to need more training was higher in 2012. The same happened with the percentage of teachers who admitted to need more assistant teachers and the percentage of teachers who asked for more collaboration between social services and schools, and a reduction of teaching hours. Many professional claim a new pedagogical capability: resilient teachers who contribute to social development of people who are vulnerable and at significant risk are needed (Day \% Gu, 2015; Henderson \& Milstein, 2003; Neeman, 2009; Roomaring, Zwetsloot, Bos, \& Wiezar, 2014).

As regards the need of pedagogical services, the percentage is higher again in 2012. Nowadays there's a bigger heterogeneity among students that could be favorable to education, because it enriches the formative process. But it has to be admitted that there's a teaching unrest because it makes difficult the learning-teaching process. However, teachers in 1999 asked for more resources than teachers in 2012 because public investments was clearly lower (investments grew an average bigger than 7\% a year since 1999 until 2010 (MEC, 2013).

\section{Conclusion}

Once the dates were analyzed and compared with similar studies, it can be concluded that conflictivity in secondary school has decreased compared with the first study (García \& Martínez, 2001), especially according to students' opinion. This reality is reflected in a lot of European countries, because of that it cannot be considered just an isolated event from Spain.

Teachers did not link the school background with the causes of conflicts but with the social or family background or with students, although some students have not a really good image of teachers and that affects 
¿Crece la conflictividad escolar? Percepciones de estudiantes y profesorado de Secundaria

Inmaculada Hernando Mora y Roberto Sanz Ponce

their opinion about climate school. Furthermore, teachers claim more training to face school conflictivity. According to the results male teachers and those teachers who work in private school feel to be more ready for facing school conflicts. It is necessary to point out that these results just reflect teachers' opinion.

It can be as well concluded from this study that family situation affects to achievement and therefore students' attitude towards school. It has been shown that an unstable family situation increases the likelihood of misbehaviour and negative achievement.

Although our results show that climate school is improving, it would be interesting to repeat this study in next years in order to confirm our results nowadays.

\section{References}

ANDERSON, C. A., BERKOWITZ, L., DONNERSTEIN, E., HUESMANN, L. R., JOHNSON, J. D., LINZ, D. ... \& WARTELLA, E. (2003). The influence of media violence on youth. Psychological science in the public interest, 4(3), 81-110.

ANDREOU, E. (2000). Bully/victim problems and their association with psychological constructs in 8-to 12-year-old Greek schoolchildren. Aggressive behavior, 26(1), 4956.

ANDREOU, E. (2001). Bully/victim problems and their association with coping behaviour in conflictual peer interactions among school-age children. Educational Psychology, 21(1), 59-66.

ANDREOU, E. (2004). Bully/victim problems and their association with Machiavellianism and self-efficacy in Greek primary school children. British Journal of Educational Psychology, 74(2), 297-309.

ANDREOU, E. (2006). Social preference, perceived popularity and social intelligence relations to overt and relational aggression. School Psychology International, 27(3), 339-351.

ANDREOU, E. (2015). School Violence Prevention: The Youth Development Perspective. British Journal of Education, Society \& Behavioural Science 5(4): 389-395.

ARCHER, J., \& COYNE, S. M. (2005). An integrated review of indirect, relational, and social aggression. Personality and Social Psychology Review, 9(3), 212-230.

AVILÉS, J. M., \& MONJAS, I. (2005). Estudio de incidencia de la intimidación y el maltrato entre iguales en la educación secundaria obligatoria mediante el cuestionario $\mathrm{Cl}$ MEI (Avilés, 1999) -Cuestionario sobre Intimidación y Maltrato Entre Iguales-. Anales de Psicología, 21(1), 27-41.

BALDRY, A. C., Y FARRINGTON, D. P. (1998). Parenting influences on bullying and victimization. Legal and Criminological Psychology, 3(2), 237-254.

BALDRY, A. C., Y FARRINGTON, D. P. (2005). Protective factors as moderators of risk 
¿Crece la conflictividad escolar? Percepciones de estudiantes y profesorado de

Secundaria

Inmaculada Hernando Mora y Roberto Sanz Ponce

factors in adolescence bullying. Social Psychology of Education, 8(3), 263-284.

BERGUNO, G., LEROUX, P., MCAINSH, K., \& SHAIKH, S. (2004). Children's experience of loneliness at school and its relation to bullying and the quality of teacher interventions. The Qualitative Report, 9(3), 483-499.

BERTHOLD, K. A., \& HOOVER, J. H. (2000). Correlates of bullying and victimization among intermediate students in the Midwestern USA. School Psychology International, 21(1), 65-78.

BJORKVIST, K., LAGERSPETZ, K.M.J. \& KAUKAINEN, A. (1992). Do girls manipulate and boys fight? Developmental trends in regard to direct and indirect aggression. Aggressive Behavior, 18, 117-127.

BORG, M. G. (1999). The extent and nature of bullying among primary and secondary schoolchildren. Educational research, 41(2), 137-153.

CAVA, M. J., MUSITU, G., \& MURGUI, S. (2007). Individual and social risk factors related to overt victimization in a sample of Spanish adolescents. Psychological Reports, 101(1), 275-290.

CHESTER, K. L., CAlLAGHAN, M., COSMA, A., DONNElly, P., CRAIG, W., WAlSH, S., \& MOLCHO, M. (2015). Cross-national time trends in bullying victimization in 33 countries among children aged 11, 13 and 15 from 2002 to 2010. The European Journal of Public Health, 25(suppl_2), 61-64.

CRICK, N. R. \& GROTPETER, J. K. (1995) Relational Aggression, Gender and SocialPsychological Adjustment. Child Development 66, 710-22.

DAY, C. \& GU, Q. (2015). Educadores resilientes, escuelas resilientes. Construir y sostener la calidad educativa en tiempos difíciles. Madrid: Narcea.

De BRUYN, E. H., CILLESSEN, A. H., y WISSINK, I. B. (2010). Associations of peer acceptance and perceived popularity with bullying and victimization in early adolescence. The Journal of Early Adolescence, 30(4), 543-566.

DEFENSOR DEL PUEBLO-UNICEF, 1999-2006. (2007). Informes, estudios y documentos. Violencia escolar: el maltrato entre iguales en la Eduación Secundaria Obligatoria 1999-2006. Madrid, Publicaciones de la Oficina del Defensor del Pueblo

DEFENSOR DEL PUEBLO-UNICEF. (2000). Informe sobre violencia escolar. Madrid: Oficina del Defensor del Pueblo.

FÉLIX, V., SORIANO, F. y GODOY, C. (2009). Un estudio descriptivo sobre el acoso y violencia escolar en la Educación Obligatoria. Escritos de Psicología, 2,43-51.

GARCÍA, R. y MARTíNEZ R. (coord.) (2001). (Grupo CICA). Los conflictos en las aulas de ESO. Un estudio sobre la situación en la Comunidad Valenciana. Valencia: L'Ullal Edicions.

GLOVER, D., GOUGH, G., JOHNSON, M., \& Cartwright, N. (2000). Bullying in 25 secondary schools: Incidence, impact and intervention. Educational Research, 42(2), 141-156.

GOBIERNO VASCO (2004). Educación para la convivencia y la paz en los centros escolares de la Comunidad Autónoma del País Vasco. Vitoria: Servicio Central de Publicaciones del Gobierno Vasco.

HENDERSON, N. \& MILSTEIN, M. (2003). Resiliency in schools: making it happen for students and educators. Thousand Oaks, CA: Corwin Press. 
¿Crece la conflictividad escolar? Percepciones de estudiantes y profesorado de Secundaria

inmaculada Hernando Mora y Roberto Sanz Ponce

IBORRA, I. RODRÍGUEZ, A., SERRRANO, A. y MARTíNEZ, P. (2010). Situación del menor en la Comunidad Valenciana: víctima e infractor. Serie documento, 18. Valencia: Centro Reina Sofía para el estudio de la violencia.

MINISTERIO DE EDUCACIÓN, CULTURA Y DEPORTE (2013). Informe 2013 sobre el estado del sistema educativo. Madrid: Secretaría General Técnica. Subdirección General de Documentación y Publicaciones.

NEEMAN, M. (2009). Developing resilience. Hove, East Sussex: Routledge.

OCDE (2011). ¿Se ha deteriorado la disciplina en los centros? Pisa in focus, 4.

OCDE (2013). ¿Qué piensan los estudiantes sobre la escuela? Pisa in focus, 24.

OLWEUS, D. (1993). Bullying at school: What we know and what we can do. Oxford: Wiley-Blackwell.

OLWEUS, D. (1996). Bully/victim problems at school: Facts and Effective intervention. Reclaiming children and youth: Journal of Emotional and Behavioral Problems, 5(1) 15-22. National Educational Service.

OLWEUS, D. (2006). Conductas de acoso y amenaza entre escolares. Madrid: Ediciones Morata, S.L.

OÑEDERRA, J. A. (2004). Educación para la convivencia y la paz en los centros escolares de la Comunidad Autónoma del País Vasco. Vitoria: Servicio Central de Publicaciones del Gobierno Vasco.

PELEGRÍN, A., \& DE LOS FAYOS, E. J. G. (2008). Variables contextuales y personales que inciden en el comportamiento violento del niño. European Journal of Education and Psychology, 1(1), 5-20.

PERLUS, J. G., BROOKS.RUSSELL, A.,, WANG, J. \& IANNOTTI, R. J. (2014). Trends in Bullying, Physical Fighting, and Weapon Carrying Among 6th- Through 10th-Grade Students From 1998 to 2010: Findings From a National Study. American Journal of Public Health, 104(6), 1100-1106.

RAMOS, M. J. (2008). Violencia y victimización en adolescentes escolares. (Tesis doctoral). Universidad Pablo de Olavide, Sevilla.

RIGBY, K. (2000). Effects of peer victimization in schools and perceived social support on adolescent well-being. Journal of adolescence, 23(1), 57-68.

RIGBY, K. \& SMITH, P. K. (2011). Is school bullying really on the rise?. Social Psychology of Education, 14(4), 441-455.

ROOMARIJN, M.C.; ZWETSLOOT, G.I.J.M.; BOS, E. H., \& WIEZER, N. M. (2014). Exploring teacher and school resilience as a new perspective to solve persistent problems in the educational sector.Teachers and Teaching: Theory and Practice, 2015, 622637.

SCHNEIDER, S. K., O'DONNELL, L., \& SMITH, E. (2015). Trends in Cyberbullying and School Bullying Victimization in a Regional Census of High School Students, 2006 2012. Journal of school health, 85, 611-620.

SíNDIC DE GREUGES DE LA COMUNIDAD VALENCIANA (2007). La escuela: espacio de convivencia y conflictos. Alicante: Síndic de Greuges.

SLEE, P. T., \& RIGBY, K. (1993). The relationship of Eysenck's personality factors and selfesteem to bully-victim behaviour in Australian schoolboys [Abstract].Personality and individual differences 14(2), 371-373. 
¿Crece la conflictividad escolar? Percepciones de estudiantes y profesorado de

Secundaria

Inmaculada Hernando Mora y Roberto Sanz Ponce

WANG, J., IANNOTTI, R. J., \& NANSEL, T. R. (2009). School bullying among adolescents in the United States: Physical, verbal, relational, and cyber. Journal of Adolescent health, 45(4), 368-375.

VIENO, A., LENZI, M., GINI, G., POZOLLI, T. CAVALLO, F., \& SANTINELLO F. (2015) Time trends in bully behavior in Italy. Journal of School Health, 85, 441-445.

ZIMMER-GEMBECK, M. J., \& LOCKE, E. M. (2007). The socialization of adolescent coping behaviours: Relationships with families and teachers. Journal of adolescence, $30(1), 1-16$. 
